Sciendo Порівняльна професійна педагогіка 9(3)/2019 Comparative Professional Pedagogy 9(3)/2019

DOI: $10.2478 /$ rpp-2019-0026

PhD in Pedagogy, Associate Professor, OLESIA SADOVETS Khmelnytskyi National University Address: 11 Instytutska St., Khmelnytskyi, 29016, Ukraine E-mail: lesyasadovets@gmail.com

\title{
THE RELEVANCE OF APPLIED LINGUISTICS IN RELATION TO LANGUAGE AND COMMUNICATION STUDIES: A WORLDWIDE OVERVIEW
}

\begin{abstract}
The paper outlines the peculiarities of Applied Linguistics as a branch of science and specialty provided by universities worldwide. Its scope, relevance in modern labour market and immediate relation to communication and language studies have been analyzed. Its advantages as a flourishing educational program for tertiary education and as an occupation in modern digital world with diverse realms of communication and language application have been substantiated. A wide range of activities pressuposed by Applied Linguistics study have been outlined: researching language in classrooms (classroom-based research); work with different kinds of written and spoken texts (corpus linguistics); approaching language learning (learner autonomy); testing and assessment of language learning; expanding vocabulary (including multiword expressions); dictionary making; interpretation and translation; studies of bilingualism and multilingualism. It has been determined that five most important concepts are basic for understanding the relation of Applied Linguistics to language and communication studies: Functional Linguistics, Language and its Application, Communicative Competence; Cognitive Discourse Analysis, Conceptual Blending Theory, and Contemporary Discourse Analysis; Barriers in Specialized Translation fields and their overcoming (by means of technology); Linguistics and Culture; Language hierarchy, authority, policy, and planning. Applied Linguistics program in tertiary education provides students with necessary studies in relation to language and communication in terms of language communication, its components, conditions of successful communication and cooperation; language etiquette; speech codes, their switching and mixing; speech acts and their types; context of culture, situation and co-texts; assembling and working with corpora; researching collocations and units of meaning. Undergoing the program of Applied Linguistics in tertiary education students can broaden knowledge of linguistics and language; deal with contemporary issues concerning the diversity of languages and cultures in societies; learn and teach foreign languages; eliminate language and communication gaps between people of different cultures; enhance the development of languages and communication skills.
\end{abstract}

Keywords: Applied Linguistics, communication, language studies, Applied Linguistics program.

\section{АНОТАЦІЯ}

У статті окреслено спеиифіку «Прикладної лінгвістики» як галузі знань та спеціальності, яка пропонується закладами вищзоі освіти у всіьому світі. Проаналізовано їі зміст, актуальність на сучасному ринку праці та безпосередній зв'язок з вивченням комунікації та мови. Обгрунтовано ї̈ переваги як перспективної освітньої програми для закладів вищьї освіти та як професії у сучасному ичифровому світі з різноманітними галузями комунікації та застосування мови. Визначено 
sciendo Порівняльна професійна педагогіка 9(3)/2019

Comparative Professional Pedagogy 9(3)/2019

широкий спект видів діяльності, які передбачені вивченням освітньої програми $з$ «Прикладної лінгвістики»: дослідження мови в освітньому середовищі, робота з усними і письмовими текстами (корпусна лінгвістика), використання різних підходів до вивчення мови, тестування та оцінювання знання мови, укладання словників, робота з лексикою, усний та письмовий переклад, вивчення білінгвізму та мультилінгвізму. 3'ясовано, щзо для обгрунтування безпосереднього зв'язку «Прикладної лінгвістики» 3 вивченням мови та комунікації базовими є пять основних концептів: 1) систематична функціональна лінгвістика, функиіі мови та комунікативна компетентність; 2) когнітивний аналіз дискурсу, аналіз сучасного дискурсу та теорія концептуального поєднання; 3) галузі спеціалізованого перекладу, його труднощчі та їх подолання $з$ використанням технологій; 5) лінгвістика і культура, ієрархія мови, ї̈ планування та функиіонування. Освітня програма з «Прикладної лінгвістики» у закладах вищої освіти забезпечує студентів навчанням, спрямованим на вивчення мови та комунікачії у таких напрямах: мовна комунікація, ї̈ компоненти, умови успішного здійснення цьього процесу, комунікативна співпраця; мовний етикет; мовні коди, їх зміна та змішування; мовні акти та їхні типи; контекст культури, ситуації та речення; укладання корпусів та робота з ними; словосполучення, сталі вирази та значущі одиниці. 3'ясовано, щуо у процесі вивчення «Прикладної лінгвістики» студенти розщирюють знання з лінгвістики та мови, досліджують сучасні проблеми різноманітності мов та культур у світі, вивчають та викладають іноземні мови, заповнюють прогалини у комунікаціі представників різних культур, формують комунікативну компетентність.

Ключові слова: прикладна лінгвістика, комунікачія, комунікативна компетентність, освітня програма з «Прикладної лінгвістики».

\section{INTRODUCTION}

Language and communication are indispensable part of contemporary life. They help us understand thoughts and actions of people around us - from decoding of simple messages to trying to comprehend our feelings and emotions, relations with friends and family, understanding the difference between cultures and communication systems and their recognition in real life situations. Due to all these factors specialists knowledgeable in language and communication are in great demand today, when communication acquires different means of expression and is applied in various situations. In this respect Applied Linguistics specialty appears to be up to date especially with the development of technology and intercultural communication.

Sometimes this specialty is underestimated by society and prospective students because they do not really realize the scope of this branch of science. The problem is that applied linguists themselves don't completely comprehend the subject they study. They argue over whether it is connected with language teaching or with theoretical linguistics and whether it includes the practical application of the language. All of these views are peculiar to applied linguists and are presented in the BA courses available at universities all over the world under the label of Applied Linguistics. To some, this specialty means applying theoretical linguistics to actual data, to others it is something related to the compillation of dictionaries or the collection of "corpora", while others think that specialists in Applied Linguistics are those describing the language of social networks or looking for gender neutral vocabulary. Applied Linguistics seems rather broad, including the study of first language acquisition and computational linguistics (Cook, 2018). 


\section{THE AIM OF THE STUDY}

The paper is aimed at the analysis of Applied Linguistics as a specialty and a science, defining its scope, relevance in modern labour market and demonstrating its immediate relation to communication and language studies as well as substantiating its advantages as a flourishing educational program for tertiary education and as an occupation in modern digital world with diverse realms of communication and language application.

THEORETICAL FRAMEWORK AND RESEARCH METHODS

The issue of Applied Linguistics is not new in scientific literature and is covered in works of a number of researchers all around the world: Cook V. (2018), J. Holmes (2011), M. Marra (2011), R. Nordquist (2019), I. Piller (2017), V. Walsh (2019), P. Warren (2017) and others. In their works the researchers try not just to disclose the essence of Applied Linguistics as a science but explain its practical implementation, its relation to communication and language studies.

The most renowned names in Applied Linguistics which are considered to be the founders of it as a science are N. Chomsky (1991), A. Firth (2007), M. Halliday (2003), D. Hymes (1996) and others. They made a foundation for further development of the science and formulated its main postulates.

The works of the above mentioned scientists were used in this research to demonstrate the practicality and necessity of Applied Linguistics as a science and as a specialty (profession), to demonstrate its focal place in relation to communication and language studies. In the research we have used a range of general scientific methods (including study and analysis of reference, scientific educational print and on-line sources), as well as systematization and generalization. Our research is qualitative (descriptive) and includes observation, document analysis, and narrative inquiry.

\section{RESULTS}

Applied linguistics is a field of study that studies the ways linguistics can assist in dealing with issues in areas such as psychology, sociology and education. It is closely related to theoretical linguistics, which studies areas such as morphology, phonology and lexis. Branches of applied linguistics that are of interest to teachers of languages include language acquisition, corpus studies and sociolinguistics (British Council, 2019). It connects the study of language (Linguistics) with the teaching and learning of languages.

Applied Linguistics embraces a wide scope of branches,such as:

- researching language in the process of learning (classroom-based research);

- working with different kinds of written and spoken texts (corpus linguistics);

- using various approaches to language learning (learner autonomy);

- testing and assessment of language learning;

- researching and expanding vocabulary (including multiword expressions);

- dictionary making;

- interpretation and translation;

- studies of bilingualism and multilingualism.

Studying applied linguistics presupposes enchancing our understanding of how language functions in a wide range of personal, social and professional relations and interactions. It is also related to our communication with each other, negotiation and establishing effective cooperation.

Within Applied Linguistics program, one can learn how to use written and spoken modes effectively, and how the way one communicates enhances or hinders interaction. The Applied Linguistics program includes practical issues that are closely connected with 
Sciendo Порівняльна професійна педагогіка 9(3)/2019 Comparative Professional Pedagogy 9(3)/2019

establishing relationships between languages, cultures and societies; the acquisition of second and foreign languages; teaching and learning of languages; language policy; and intercultural communication (British Council, 2019).

A degree in Applied Linguistics will provide a student with possibilities to:

- obtain substantial knowledge of linguistics and language;

- research diversity of languages and cultures in contemporary societies;

- develop the ability to learn and teach foreign languages;

- overcome language and communication gaps between people of different cultures;

- encourage young people to develop language and communication skills.

Those undergoing educational program in Applied Linguistics will study the Functioning of Languages, Linguistics, Second language acquisition, Culture and communication, Intercultural communication in everyday life, Language and society.

Applied linguistics explains the interaction between languages and communication, provision of their effective application in all contexts. The acquired skills can be applied in many spheres and industries, among which are emerging areas of machine translation, speech recognition and human-computer interaction.

Prospective jobs that one can get after completion of the Applied Linguistics program are: language teacher; forensic linguistics specialist; professional writer; communication advisor; interpreter and translator, copywriter.

It is quite obvious that in the process of studying Applied Linguistics one will definitely acquire a competence necessary to engage oneself in a number of jobs and professions related to language and communication, as it is the focal point of its curriculum.

To understand the relation of Applied Linguistics to communication and language studies it is necessary to highlight the basic concepts (for linguists): Competence.

1. Functional Linguistics, Functioning of Language, and Communicative

In this relation it is necessary to highlight two most important personalities in the field of Applied Linguistics. They are Dell Hymes (Hymes, 1996) and M. Halliday (Halliday, 2003). Their primary research concerned language use in relation to discourse, meaning, and communication in speech and text.

M. Halliday studied social contexts of language, namely the field of discourse; the tenor of discourse; the mode of discourse.

These issues made up the foundation of theory on functions of language:

- Expression of semantic content;

- Exchange of semantic content;

- Structuring of semantic content in the text (Halliday, 2003).

This is the basis for the development of D. Hymes' Theory of Communicative Competence that comprises the knowledge of where, when, and with whom it is appropriate to use certain utterances and/or grammar in speech situations (ceremonies, trips), speech events (ordering food, giving a lecture), or speech acts (greetings, compliments) (Hymes, 1996).

D. Hymes formulated five communicative competences - functional, grammatical, cultural, interactional, and sociolinguistic (when to speak, how one should speak depending on culture, with which register to speak, and which body language/level of formality to use) (Hymes, 1996).

For professional linguists it is vital to comprehend or, at least, have some knowledge about relations and connections among different cultural and linguistic communities, their speech and means of interaction. Speakers must know with whom they 
are communicating and how to do it properly, otherwise misunderstandings are sure to take place (Walsh, 2019).

2. Cognitive Discourse Analysis, Conceptual Blending Theory, and Contemporary Discourse Analysis.

Cognitive Discourse Analysis is an approach that considers cognitive or mental processes which are responsible for the production and comprehension of discourse, speech, or text. These aspects are especially important for those who want to overcome communication gap between different cultures. If two people are aware of social essence of the cultures they try to unite, their common efforts will make communication more understandable (Walsh, 2019).

This leads to a concept of conceptual blending theory, that is aimed at explaining of how the meaning of a text is understood in real life by a listener (or reader) with the help of linguistic hints that enhance mental processes. This is especially useful in the branch of translation, as it helps to outline the most productive means to transmit the original message so that it sounds understandable and natural to the target audience - usually via emotions. This theory highlights the necessity to pay attention not only to linguistic correctness but to more profound mental and emotional levels (Walsh, 2019).

The theory of Contemporary Discourse Analysis is based on reflexive thoughts (related to culture, values, and beliefs) and how they influence the meaning and interpretation of a text (Gee \& Hayes, 2011). An acclaimed linguist James Gee states that before a text becomes a text, it must be produced. After that it is perceived on the basis of different contexts - linguistic, temporal, interpersonal, and geographical. That's why professional translators working with various cultures around the world must take different contexts into consideration while delivering the final message to the clients.

3. Barriers in Specialized Translation and their overcoming (by means of technology).

It is quite clear that there are many different brances of science that undergo translation process (general, medical, IT, political, economic, legal, technical, literary, etc.) and that are characterized by different ranges of vocabulary, expertise, and comprehension. They must be considered by linguists and especially translators. Besides, translators must concentrate on three main factors that help to transmit the message to the client in a proper way: clarity, understandability, and economy. The task of a professional translator is to combine grammatical correctness and perception of the text as a whole. In this respect translation technology plays crucial role - it gives modern translators a major advantage. Nevertheless, it is the task of a human translator to apply linguistic skills to align the information received from computers to human perception. Technology assists, but still it is the task of a human translator to control the language, its clarity, consistence, understandability, and conciseness. Only under these conditions the task is accomplished (Walsh, 2019).

4. Linguistics and Culture.

It is very crucial to differentiate various cultures when it concerns communication and translation. Social, cultural, and linguistic differences must be taken into consideration to provide proper communication. Intercultural communication and consideration of cultural values are essential in delivering a message across cultures.

It is an established fact that lexical units have many different meanings depending on various concepts and interpretations, and it is the job of professional communicators and linguists to choose the correct and appropriate one. They must research the source material and target audience to be absolutely sure of the meaning they choose. 
Sciendo Порівняльна професійна педагогіка 9(3)/2019 Comparative Professional Pedagogy 9(3)/2019

Being aware of cultural and national differences between people is a crucial condition of efficient communication and intercultural relationships in general, the same can be said about translation and interpretation (Walsh, 2019).

5. Language hierarchy, authority, policy, and planning.

Frequently, linguists face the choice concerning the type of language they have to use (formal vs. informal language, as well as accents, dialects, and intonation). Linguist and philosopher Noam Chomsky states that often relations between a speaker and listener can create real hierarchies (Chomsky, 1991).

One of the most important issues in this relation is language planning that can be very useful for a number of aims, namely: keeping up languages, helping immigrants integrate into a new cultural community and learn their language, enhancing intercultural interaction and cooperation, and helping overcome cultural problems related to communication between different groups (oral or written). Moreover, translators should pay attention to developments in language policy/planning and consider them before presenting their final work, because a word or expression can have quite opposite meanings in different languages and cultures (Walsh, 2019).

The consideration of these concepts of Applied Linguistics as a science is the foundation of designing and implementation of Applied Linguistics educational program into tertiary education, in which communication and language studies are among the main aims and branches of study. Applied Linguistics educational program is designed to incorporate the study of communication, language and effective interaction of people. Completion of this program presupposes that students must be knowledgeable in:

1. Language communication, its components (speaker, recipient, message, context, specificity of contact and code (means) of speech), conditions of successful communication and cooperation (implementation of Paul Grice's conversational maxims (of quantity, quality, relation and manner), as well as defining cases of their violation and flouting).

2. Language etiquette (an accepted set of requirements for forms, content, orders, characters and situational relevance of utterance or expression);

3. Speech codes (frameworks for communication in a given speech community), their switching and mixing;

4. Speech acts (an utterance defined in terms of a speaker's intention and the effect it has on a listener) and their types (locutions, illocutions, perlocutions).

5. Context of culture, situation (the total environment, including the verbal environment and the situation in which the text was produced) and co-texts (words of a text that are surrounded by their linguistic environment).

6. Assembling and working with corpora (a large collection of texts electronically stored on a computer, containing authentic language used in real situations and representing both the language used in speech and in writing); students learn how to use corpora to check patterns of the language and its lexico-grammatical features; check the use of words; compare the use of words in different varieties of the same language (for example, either in the language of economics or in the language of medicine etc.); compare and contrast translation equivalents across different languages; draw examples for the preparation of teaching material; obtain a list of the phraseology and the terminology of a language and its varieties;

7. Collocations and units of meaning (interrelation of words in a close proximity and their influence on the general meaning of collocations).

The students use qualitative and quantitative research methods for undertaking their own empirical and/or theoretical research into language and language behaviour, sub- 
domains of applied linguistics such as first and second language acquisition, intercultural communication, language pedagogy and assessment, language impairment, language policy and language and identity. These branches of research demonstrate direct relation of Applied Linguistics to communication and language.

\section{CONCLUSIONS}

Thus, having considered the essence of Applied Linguistics as a science and as an educational program in tertiary education we have come to the conclusion that its basic notions are language and communication. Students undergoing studying in this program learn how language functions and influences communication. To show the relation between Applied Linguistics and communication it's necessary to deferentiate five basic concepts of Applied Linguistics which are: Functional Linguistics, Functions of Language, and Communicative Competence; Cognitive Discourse Analysis, Conceptual Blending Theory, and Contemporary Discourse Analysis; Barriers in Specialized Translation fields and their overcoming (with the help of technology); Linguistics and Culture; Language hierarchy, authority, policy, and planning.

Applied Linguistics program in tertiary education provides students with substantial studies in relation to language and communication in terms of language communication, its components, conditions of successful communication and cooperation; language etiquette; speech codes, their switching and mixing; speech acts and their types; context of culture, situation and co-texts; assembling and working with corpora; studying and researching collocations and units of meaning.

The prospect of further research is the possibilities of connecting linguists' professional knowledge of languages for promotion of e-communication with the use of Information Technology.

\section{REFERENCES}

1. British Council. (2019). Applied linguistics. Retrieved from: https://www.teachingenglish.org.uk/article/applied-linguistics.

2. Chomsky, N. (1991). Linguistics and Cognitive Science: Problems and Mysteries. Oxford: Blackwell.

3. Cook, V. (2018). What is applied linguistics. Retrieved from: http://www.viviancook.uk/ Writings/Shorts/WhatisALl.htm.

4. Firth, A. \& Wagner, J. (2007). Second/foreign language learning as a social accomplishment: elaborations on a "reconceptualised" SLA. Modern Language Journal, 91, 800-819.

5. Gee, J. P. \& Hayes, E. (2011). Language and Learning in the Digital Age. London and New York: Routledge.

6. Halliday, M. (2003). On the "architecture" of human language. In: On Language and Linguistics, Vol. 3. London and New York: Equinox.

7. Holmes, J., Joe, A., Marra, M., Newton, J., Riddiford, N. \& Vine, B. (2011). Applying linguistic research to real world problems: the case of the Language in the Workplace Project. In Christopher, N. (ed.) Handbook in Applied Linguistics: Communication in the Professions, 533-549. Berlin: Mouton de Gruyter.

8. Hymes, D. (1996). Ethnography, Linguistics, Narrative Inequality: Toward an Understanding of Voice. London: Taylor \& Francis. 
Sciendo Порівняльна професійна педагогіка 9(3)/2019

Comparative Professional Pedagogy 9(3)/2019

9. Marra, M., \& Warren, P. (2017). Linguist at Work: Festschrift for Janet Holmes. Wellington: Victoria University Press.

10. Nordquist, R. (2019). Applied Linguistics. ThoughtCo, Jul. 3, 2019. Retrieved from: thoughtco.com/what-is-applied-linguistics-1689126.

11. Piller, I. (2017). Intercultural Communication: A Critical Introduction. Edingburgh University Press.

12. Walsh, V. (2019). The Mysterious Field of Applied Linguistics and how it Relates to Translation. Retrieved from https://theopenmic.co/the-mysterious-field-ofapplied-linguistics-and-how-it-relates-to-translation/. 